РОЛЬ СОЦІОКУЛЬТУРНОГО КОМПОНЕНТУ

У ФОРМУВАННІ КОМУНІКАТИВНОЇ КОМПЕТЕНТНОСТІ

В ПРОЦЕСІ ВИВЧЕННЯ УКРАЇНСЬКОЇ МОВИ ЯК ІНОЗЕМНОЇ

\title{
THE ROLE OF THE SOCIO-CULTURAL COMPONENT IN FORMATION OF COMMUNICATIVE COMPETENCE IN THE PROCESS OF LEARNING THE UKRAINIAN LANGUAGE AS FOREIGN
}

У статті розкрито роль соціокультурного компоненту при формуванні комунікативної компетентності у процесі вивчення української мови як іноземної для здобуття вищої освіти іноземними студентами. Вказано на основні тендениії розвитку сучасної освіти, які впливають на популярність і престижність отримання фраху іноземними громадянами в Україні. Подані статистичні дані Українського державного чентру міжнародної освіти при Міністерстві освіти і науки України про зростання кількості іноземних студентів у закладах освіти України, що $\epsilon$ свідченням зростання міжнародного автоpumemy України у ссрері надання освітніх послуг.

У роботі вказана нормативна база, яка забезпечує викладання навчальної дисципліни «Українська мова як іноземна» іноземним студентам. Основна мета курсу - сформувати комунікативну компетентність шляхом вироблення в іноземних студентів необхідних мовних і мовленнєвих умінь у всіх видах мовленнєвої діяльності, щоб забезпечити їм можливість спілкування в українському мовному середовищі (навчання, побут, культура) та здобуття спеціальності. Доведено, що мова навчання є інструментом і водночас гарантією якісноі профресійної підготовки, а тому оволодіння українською мовою як іноземною є одним із пріоритетних завдань для іномовних студентів при опануванні майбутньою професією в Україні.

у статmі розглянуто співвідношення понять «комунікативна компетентність» i «комунікативна компетенція» та проаналізовано їх компоненти: мовний, мовленнєвий, соціокультурний; досліджено, що четвертий компонент трактується по-різному: інтеркультурний, діяльнісний (стратегічний), прагматичний. Розкрито сутність соціокультурного компоненту комунікативної компетентності через систему взаємопов'язаних складників: країнознавчого, лінгвокраїнознавчого, соціолінгвістичного.

Доведено значущість ролі соціокультурного компоненту при мовленнєво-культурній адаптації іноземних студентів до українського культурно-мовленнєвого середовища при їх інтеграції в український сочіум, освіту, культуру, побут. Соціокультурний компонент відіграє значну роль при фрормуванні в іноземних студентів соціокультурних знань, навичок, набутті практичних умінь у соціально-культурній, навчально-професійній і навчально-науковій ссрерах із метою формування комунікативної компетентності, яка сприяє професійному, культурному, творчому розвитку та становленню мовної особистості майбутнього фрахівця. Ключові слова: соціокультурний компонент, іноземні студенти, фрормування кому- нікативної компетентності, українська мова як іноземна, україномовне середовище, мовленнєво-культурне середовище.

The role of the socio-cultural component in the formation of communicative competence in the process of studying Ukrainian as a foreign language for higher education by foreign students is revealed in the article. The main tendencies of the development of modern education, which influence the popularity and prestige of obtaining the profession of foreign citizens in Ukraine, are pointed out. The statistics provided by the Ukrainian State Center for International Education at the Ministry of Education and Science of Ukraine on the growth of the number of foreign students in educational establishments of Ukraine is a testimony to the growth of Ukraine's international authority in the field of educational services.

The paper specifies the legal framework that provides the teaching of the discipline "Ukrainian as a foreign language" to foreign students. The main objective of the course is to form a communicative competence by developing the necessary language and speech skills in all types of speech activities for foreign students to enable them to communicate in the Ukrainian language environment (education, everyday life, culture) and gain a specialty. It is proved that the language of instruction is an instrument and at the same time a guarantee of quality vocational training, and therefore mastering Ukrainian as a foreign language is one of the priority tasks for foreign language students in mastering their future profession in Ukraine.

The article considers the relation between the concepts of "communicative competence" and "communicative competence" and analyzes their components: linguistic, speech, socio-cultural; investigated that the fourth component is interpreted differently: intercultural, activity (strategic), pragmatic. The essence of the sociocultural component of communicative competence is revealed through a system of interrelated components: country, linguistic, sociolinguistic. The importance of the role of socio-cultural component in the speech and cultural adaptation of foreign students to the Ukrainian cultural and speech environment is proved; at their integration into the Ukrainian society, education, culture, life. The socio-cultural component plays a significant role in the formation of socio-cultural knowledge, skills, acquisition of practical skills in socio-cultural, educational-professional and educational-scientific spheres for foreign students in order to form a communicative competence that promotes professional, cultural, creative development and creativity specialist.

Key words: socio-cultural component, foreign students, formation of communicative competence, Ukrainian as a foreign language, Ukrainian language environment, speecher-cultural environment. 
Постановка проблеми в загальному вигляді. Інтеграційні процеси у сорері вищої освіти посилюють зближення й гармонізацію національної системи вищої освіти із загальноєвропейським науковим та освітнім простором. Інтернаціоналізація, зміцнення міжнародного співробітництва, гуманізація і гуманітаризація, повага до загальнолюдських цінностей, міжкультурна комунікація, активізація академічної мобільності, дотримання принципів академічної доброчесності - основні тенденції розвитку сучасної освіти, які впливають на вибір іноземних громадян навчатися у закладах вищої освіти (далі - 3ВО) України.

Політика у сорері освіти сприяє національному та міжнародному визнанню кваліфікацій, здобутих в Україні. Національна рамка кваліфікацій - системний і структурований за компетентностями опис кваліфікаційних рівнів, який грунтується на європейських і національних стандартах і принципах забезпечення якості освіти [9]. Це є одним із фракторів, чому іноземні громадяни їдуть навчатися в Україну, щоб отримати диплом, який гарантуватиме їм у майбутньому професійну реалізацію та кар'єрне зростання у будь-якій країні світу.

Аналізуючи питання надання якісних освітніх послуг українськими ЗВО іноземним громадянам, А. Черняк звертає увагу на проблемні аспекти, пов'язані 3 перебуванням і навчанням іномовних студентів, зокрема володіння ними мовою навчання: «... виникають обґрунтовані сумніви, чи засвоїли студенти з Азербайджану, Туркменістану та інших країн навчальні дисципліни і чи гідні вони отримати у подальшому дипломи про вищу юридичну, економічну чи іншу освіту. Підтверджуються побоювання за якість підготовлених фрахівців наявністю випадків, коли випускники українських 3ВО, які отримували вищу освіту українською чи російською мовами, навіть не володіють цими мовами, а про рівень засвоєння профрільних навчальних дисциплін не йдеться взагалі» [12, с. 225].

При опануванні вищої освіти в Україні іноземними громадянами постає питання комунікації, набуття комунікативної компетентності та адаптації до мовленнєво-культурного середовища, національних традицій, культурних, історичних цінностей, соціалізації в україномовному середовищі. Таким чином, на сьогодні особливої актуальності набуває питання соціокультурного компоненту при фрормуванні комунікативної компетентності у процесі вивчення української мови як іноземної (УМІ) студентами $з$ інших країн.

Аналіз останніх досліджень і публікацій свідчить про поглиблений інтерес науковців до проблеми викладання навчальної дисципліни «Українська мова як іноземна». Дослідженню підходів і методів начання УМІ присвячені праці науковців 3. Бакум, Г. Бойко, Я. Гладир, І. Жовтоніжко, І. Зелез, Т. Єфрімова, В. Костюшко, А. Кулик,
О. Огринчук, О. Пальчикова, А. Чернова, І. Чернюк. У статті І. Кочан і 3. Мацюк досліджені лінгвометодичні основи укладання підручників із навчальної дисципліни «Українська мова як іноземна». Соціально-психологічні, соціокультурні проблеми адаптації іноземних студентів до освітнього, мовного та культурного середовища розглянуто у публікаціях Н. Булгакова, Л. Бутенко, А. Гадомської, М. Іванова, Н. Смолікевич, Т. Стефаненко, В. Тарасенко, І. Шульги та інших. Проаналізовано підходи до розуміння термінів комунікативної компетентності і компетенцій, розглянуто складники цих наукових понять у працях Т. Варянко, М. Галицької, Л. Голованчук, І. Гуменної, О. Загородної, І. Закір'янової, Л. Іванченко, Т. Колодько, О. Пометун, І. Потюк та інших.

Виділення не вирішених частин загальної проблеми. На основі аналізу наукових праць із проблеми дослідження встановлено, що приділена значна увага питанню фрормування комунікативної компетентності у майбутніх педагогів, юристів, соціальних працівників та інших фрахівців, а також розглядається проблема комунікації при опануванні іноземними мовами у закладах вищої освіти в Україні. Проте, незважаючи на значну кількість наукових публікацій, залишається недостатньо вивченим вплив соціокультурного компоненту на фрормування комунікативної компетентності в іномовних здобувачів вищої освіти у процесі оволодіння українською мовою як іноземною.

Мета роботи - дослідити роль соціокультурного компоненту у формуванні комунікативної компетентності в іноземних студентів у процесі вивчення української мови як іноземної.

Виклад основного матеріалу. Враховуючи освітні тенденції на сучасному етапі, спостерігаємо збільшення кількості іноземних студентів. Статистичні дані Українського державного центру міжнародної освіти при Міністерстві освіти і науки України свідчать, що порівняно з 2017-2018 навчальним роком кількість іноземних студентів у 20182019 навчальному році зросла на 10 тисяч і становила 75605 осіб. У 2019-2020 навчальному році в закладах освіти України «навчається більше 81 тисячі іноземних студентів зі 154 країн світу (2014 рік - 63 172, 2015 рік - 63 906, 2016 рік 64 066, 2017 рік - 66 310, 2018 рік - 75 605); освітню діяльність, пов'язану з іноземними громадянами, надають близько 450 закладів вищої освіти (3 них 88\% державних, 12\% приватних)» [12, с. 221].

Збільшення кількості іноземних студентів з одного боку свідчить про зростання міжнародного авторитету України у сорері надання освітніх послуг, а з іншого на заклади вищої освіти покладається велика відповідальність у підготовці висококваліфікованих фрахівців для інших країн. Відповідно до Закону України «Про вищу освіту» українська мова у ЗВО є мовою освітнього 
процесу [5], а тому оволодіння іноземними громадянами українською мовою - це їх шлях до успіху, профресіоналізму, а також можливість саморозвиватися, самовдосконалюватися, інтегруючись в український соціум, культуру, побут, підвищувати свій фраховий і загальнокультурний рівень.

Оскільки мова навчання $€$ інструментом і водночас гарантією якісної профресійної підготовки, то студентам-іноземцям необхідно опанувати систему української мови, оволодіти мовленнєвими вміннями і навичками у тих видах і фрормах спілкування, на яких базується навчальна діяльність; сорормувати вміння і навички спілкування у навчально-професійній, суспільно-політичній і соціально-культурній ссрерах. Ці завдання покликана вирішувати навчальна дисципліна «Українська мова як іноземна», фрормуючи комунікативну компетентність, яка $€$ базовою при підготовці фахівця будь-якої галузі знань, оскільки комунікація як дескриптор Національної рамки кваліфрікацій України наявна в кожному стандарті вищої освіти, затвердженому Міністерством освіти і науки України.

У «Ліцензійних умовах провадження освітньої діяльності» зазначено, що «навчально-методичне забезпечення передбачає наявність навчальних планів з обов'язковим вивченням української мови як окремої навчальної дисципліни «Українська мова як іноземна» у разі підготовки іноземців та осіб без громадянства у закладах вищої, післядипломної, фрахової передвищої, професійної (профресійно-технічної) освіти незалежно від мови навчання» [8]. Натепер основним програмним документом для студентів-іноземців несрілологічного профрілю у ЗВО України є «Єдина типова навчальна програма 3 української мови для іноземних студентів» 2008 року, у якій визначено основну мету вивчення української мови як іноземної - це «оволодіння комунікативною компетентністю, яка досягається шляхом фрормування у студентів необхідних мовних і мовленнєвих умінь у всіх видах мовленнєвої діяльності (читання, аудіювання, усне мовлення, писемне мовлення), забезпечуючи їм можливість спілкування в українському мовному середовищі (навчання, побут, культура) та здобуття спеціальності» [3]. Програма передбачає забезпечення комунікативних потреб іноземних студентів у побутовій, соціально-культурній, навчально-професійній і навчально-науковій сорерах із метою фрормування комунікативної компетентності, яка сприяє професійному, культурному, творчому розвитку та становленню мовної особистості майбутнього фахівця.

Підтримка на державному рівні утвердження української мови як засобу спілкування у міжнародному середовищі спонукала до розроблення міжнародного сертисрікаційного іспиту з української мови як іноземної. Водночас запровадження такого іспиту $€$ необхідною умовою для підтвердження рівня володіння українською мовою. Колегія Міністерства освіти і науки України від 22.05.2018 протоколом № 5/1-7 ухвалила рішення «Про стандартизовані вимоги до рівнів володіння українською мовою як іноземною А1-C2». Таким чином оволодіння українською мовою як іноземною, фрормування комунікативної компетентності $€$ одним із пріоритетних завдань для іномовних студентів при опануванні майбутньої профресії в Україні.

У сучасних наукових дослідженнях комунікативна компетентність $€$ предметом вивчення багатьох науковців, але відсутня однозначна думка 3 приводу компонентів (складників) комунікативної компетентності, а в деяких дослідженнях використовується термін «комунікативної компетенції». Щодо пояснення понять «компетентність» і «компетенція» автор погоджується 3 думкою К. Олійник, яка вважає, що «...коли говоримо про компетентність, то йдеться про людину, яка володіє відповідною компетенцією для вирішення певних питань. Компетентність слугує якістю, характеристикою особи, яка дозволяє їй (або навіть дає право) вирішувати певні завдання, приймати рішення, судження у певній галузі. Іншими словами, компетенція $€$ нормативною, ідеальною метою освітнього процесу, яка моделює якості майбутнього випускника, а компетентність результат, рівень прояву, тобто володіння відповідною компетенцією» [10, с. 51]. Для вирішення поставленої проблеми компоненти комунікативної компетентності чи компетенції на цьому етапі дослідження не є суттєвими, а тому автор не буде акцентувати увагу на їх деорініціях.

Дослідниця І. Потюк, подаючи структурну модель взаємодії компонентів комунікативної компетенції, визначає три основні компоненти: мовний, мовленнєвий і соціокультурний [11, с. 131]. Оскільки іншомовна комунікативна компетенція $€$ складним, системним утворенням, то за дослідженнями М. Галицької, у її структурі $€$ такі компоненти: мовний, який формується в рамках академічного та професійного середовища (вдосконалення знань із лексики, граматики, семантики, фронології); мовленнєвий як уміння використовувати мовний матеріал для досягнення комунікативних, інорормативних, когнітивних, сугестивних та інших цілей (вдосконалення вмінь і навичок говоріння, аудіювання, письма, читання); соціокультурний, який сприяє більш усвідомленому оволодінню іноземною мовою як засобом спілкування, оскільки основними мотивами вивчення іноземної мови є прагнення розширення світогляду, інтерес до культури народу - носія мови, країнознавчих і лінгвокраїнознавчих реалій країни, мова якої вивчається; інтеркультурний, який пов'язаний із культурою різних народів, міжкультурною комунікацією [2, с. 44-45]. 
Розглядаючи питання реалізації концепції українськомовної підготовки іноземних громадян на підготовчих фракультетах 3ВО, Г. Іванишин визначає певні змістові лінії, які фрормують комунікативну компетентність і сприяють фрормуванню вторинної мовної особистості:

1) мовленнєва, яка передбачає удосконалення вмінь в основних видах мовленнєвої діяльності (аудіюванні, читанні, говорінні, письмі);

2) мовна (лінгвістична), скерована на фрормування мовної (лінгвістичної) компетентності, а саме знань про систему української мови, опанування ії граматичними засобами;

3) соціокультурна, яка передбачає фрормування соціокультурної компетентності шляхом створення та розвитку інтересу до України, українського народу, його історії, звичаїв, традицій, ознайомлення з духовними скарбами і видатними постатями, із загальнолюдськими моральними нормами;

4) діяльнісна (стратегічна), яка передбачає усвідомлення власної пізнавальної діяльності і має суто процесуальний характер [6, с. 26].

Відповідно до «Загальноєвропейських рекомендацій із мовної освіти: вивчення, викладання, оцінювання» комунікативна мовленнєва компетенція складається з трьох компонентів, до складу кожного з яких входять знання, вміння і навички: лінгвістичний компонент включає лексичні, фонологічні, синтаксичні знання і вміння та інші параметри мови як системи незалежно від соціолінгвістичного значення їх варіантів і від прагматичних фрункцій їх реалізації; соціолінгвістичний стосується соціокультурних умов користування мовою (правил ввічливості, норм, які регулюють стосунки між поколіннями, статями, класами та соціальними групами, лінгвістичних кодиорікацій деяких основних ритуалів у житті суспільства); прагматичний пов'язаний із фрункціональним вживанням лінгвістичних засобів: продукуванням мовних фуункцій, актів мовлення тощо [4, с. 30-31].

У сучасній педагогічній науці немає єдиного підходу до визначення складників комунікативної компетентності, проте аналіз наукової літератури показав значущість соціокультурного компоненту, оскільки він присутній у кожній із проаналізованих структур (моделей, змістових ліній) комунікативної компетентності / компетенції при вивченні іноземної мови, а для студентів з інших країн - це української мови.

Роль і важливість соціокультурного компоненту для міжкультурного спілкування підкреслюється у «Загальноєвропейських рекомендаціях із мовної освіти...», в яких зазначається, що при всій важливості академічних знаннь «з освітньої, наукової або технічної галузі емпіричні знання у сорері повсякденного життя (розпорядок дня, їжі, засоби транспорту, зв'язку та інформації) в публічній або приватній сорерах є найсуттєвішими для організації іншомовної мовленнєвої діяльності.

Знання спільних цінностей та ідеалів, прийнятих соціальними групами в інших країнах або регіонах (наприклад, релігійні вірування, табу, які виникли у процесі спільної історії) $€$ найсуттєвішими для міжкультурного спілкування» [4, с. 27]. Отже соціокультурний компонент $є$ важливим структурним елементом комунікативної компетентності й необхідною умовою для успішного здійснення комунікативного акту на міжкультурному рівні, в контексті діалогу культур.

У дослідженнях Т. Варянко, Л. Голованчук, І. Закір'янової, Л. Іванченко, Т. Колодько, І. Потюк та інших науковців соціокультурний компонент комунікативної компетентності розглядається як система взаємопов'язаних складників:

1) країнознавчого (знання про народ-носія мови, його історію, традиції, національний характер, побут, державний устрій, здобутки в галузі освіти, науки, культури);

2) лінгвокраїнознавчого (здатність сприймати мову як лінгвокультуру, в її культуроносній фрункції 3 національно-культурними особливостями);

3) соціолінгвістичного (вміння спілкуватися в соціумі, дотримуючись мовленнєвого етикету, застосовуючи невербальні засоби спілкування, враховуючи національну своєрідність суспільства тощо).

«Соціокультурна компетенція - це інтегративне утворення, яке включає країнознавчі, лінгвокраїнознавчі, соціолінгвістичні знання, вміння та навички співвідносити мовні засоби з метою та умовами спілкування; вміння організувати мовленнєве спілкування відповідно до соціальних норм поведінки, прийнятих у носіїв мови; вміння використовувати мовні засоби відповідно до національно обумовлених особливостей їх вживання» [7, с. 19].

Значуща роль соціокультурного компоненту при фрормуванні комунікативної компетентності проявляється в період адаптації студентів з інших країн до україномовного середовища. Дослідниця А. Гадомська окреслює «основні різновиди соціокультурних відомостей, які отримує іномовний комунікант у процесі занурення в україномовне соціокультурне середовище» [1, с. 47]:

1) вирішення повсякденних справ із питання побуту, харчування, здоров'я, гігієни, тобто реалізація щоденних побутових процесів;

2) спілкування між студентами, викладачами в закладі вищої освіти та з друзями, знайомими у повсякденному житті, у неформальній обстановці;

3) ознайомлення з національними надбаннями українців: мистецтвом, культурними, історичними та релігійними пам'ятками;

3) пізнання національних духовно-культурних цінностей, традицій, вірувань, соціальних символів та інших мовно-ментальних одиниць; 
4) оволодіння мовленнєвими фрормулами й кліше, розуміння проявів мовної гри та іншого [1, с. 47-48].

Соціокультурні відомості $€$ реаліями життя, зовнішніми об'єктивними чинниками, які фрормують в іноземних студентів соціокультурні знання, вміння, навички мовленнєвої діяльності у повсякденному житті та в соціально-культурній сорері. Українська мова $€$ засобом адаптації в чужому для іноземного студента мовно-культурному середовищі.

На значущість ролі соціокультурного компоненту комунікативної компетентності вказувала А. Гадомська: «...мовленнєво-культурна адаптація іноземних студентів до українськомовного культурно-мовленнєвого середовища буде ефективною, якщо посилити лінгвокраїнознавчий аспект у курсі навчання української мови як іноземної, забезпечити занурення іномовних комунікантів в активну аналітико-пошукову діяльність...» [1, с. 7].

щоб оволодіти соціокультурним компетентом у курсі української мови як іноземної, ми повинні сорормувати в іноземних студентів комунікативну компетентність як результат, володіння вміннями і навичками мовленнєвої діяльності в соціальнокультурній сфері, а для цього у програмі навчальної дисципліни передбачена така тематика: 1. Місто навчання студента. 1.1. Рідне місто студента. 2. Заклад вищої освіти, де навчається студент. 2.1. Майбутня профессія студента. 3. Україна (державний та економічний устрій). 3.1. Рідна країна студента (державний та економічний устрій). 4. Система освіти в Україні. 4.1. Система освіти в країні студента. 5. Київська Русь. 6. Київ - столиця України. 6.1. Столиця країни студента. 7. Шевченко Т.Г. - поетичний символ України.

При вивченні цих тем важливим $€$ використання як загальнодидактичних приципів (наочності, науковості, проблемності, міцності, свідомості, активності, інформаційної достатності, індивідуалізації, доступності, систематичності, послідовності, гуманізму, колективності, розвиваючого навчання), так і специорічних принципів, особливо актуальних при викладанні української мови як іноземної (полікультурної толерантності, взаємоповаги, міжкультурної взаємодії, діалогу культур).

Соціокультурний компонент при орормуванні комунікативної компетентності у курсі УМІ розкривається багатогранно через систему принципів. Для прикладу автор виокремлює принцип діалогу культур, який реалізується у студентівіноземців як через загальні уявлення про міжкультурну комунікацію, що базуються на порівнянні взаємовпливу різних культур і цивілізацій, інтерпретації явищ і подій, так і ціннісних смислів рідної та іноземної культур. Кожен народ має свого письменника - національного героя, виразника його дум і прагнень. Одним із визначних поетів китайського народу $є$ Ду Фу. Тому при вивченні теми «Шевченко Т.Г. - поетичний символ України» варто розглянути зі студентами з Китаю тему «Тарас Шевченко і Ду Фу в Києві». Іноземні студенти дізнаються, що 14.12.2017 із нагоди 25-тої річниці встановлення дипломатичних відносин між Україною та Китайською Народною Республікою відбулося в Україні відкриття скульптур українському генію - Тарасу Шевченку та співцеві китайського народу - Ду Фу.

Соціокультурний компонент змотивував студентів на опрацювання теми, яка поєднала аспекти лінгвокраїнознавчий і країнознавчий. Студенти з Китаю здійснили екскурсію у Ботанічний сад імені академіка О. Фоміна Київського національного університету імені Тараса Шевченка, у якому знаходяться скульптури Т. Шевченка та Ду Фу. Таким чином педагог прагнув розвинути в іноземних студентів міжкультурні вміння та навички: «здатність привести до спільного знаменника рідну й іноземну культури; здатність виконувати роль культурного посередника між рідною культурою та іноземною, успішно долати міжкультурні непорозуміння та конорліктні ситуації; здатність долати стереотипи у стосунках» [4, с. 157]. Соціокультурний компонент загалом впливає на фрормування особистості фахівця, його духовного світу та підвищує загальнокультурний рівень.

Висновки. Соціокультурний компонент при фрормуванні комунікативної компетентності в іномовних студентів у курсі української мови як іноземної відіграє значну роль в оволодінні соціокультурними знаннями, навичками, у набутті практичних умінь міжкультурної взаємодії, комунікації та сприяє формуванню полікультурної толерантності, позитивного ставлення до загальнолюдських цінностей, духовних надбань не лише свого народу, але й інших націй, народностей. Значущість ролі соціокультурного компоненту виявляється у процесі мовленнєво-культурної адаптації іноземних студентів до українського культурно-мовленнєвого середовища; інтеграції в український соціум, освіту, культуру, побут.

Здобуття вищої освіти в Україні студентамиіноземцями передбачає орормування освіченої, культурної особистості. Виховання у студентів загальнолюдських гуманістичних цінностей, поваги до культури різних народів, зокрема культури України, можливе при посиленні ролі соціокультурного компоненту у процесі вивчення української мови як іноземної.

Перспективи подальших досліджень автор вбачає у вивченні та висвітленні впливу соціокультурного компоненту комунікативної компетентності на фрормування та розвиток полікультурної толерантності як цінності особистості майбутнього фрахівця. 


\section{БІБЛІОГРАФІЧНИЙ СПИСОК:}

1. Гадомська А.А. Методика мовленнєво-культурної адаптації іноземних студентів засобами креолізованих рекламних текстів : дис. ... канд. пед. наук: 13.00.02. Одеса, 2017. 257 с.

2. Галицька М.М. Складники комунікативної компетентності студентів вищих навчальних закладів. Освітологічний дискурс. 2015. № 2 (10). С. 39-48.

3. Єдина типова навчальна програма з української мови для студентів-іноземців основних фракультетів несрілологічного профрілю вищих навчальних закладів України III-IV рівнів акредитації / Наук.-метод. комісія з підгот. іноз. громадян, уклад.: Л.І. Дзюбенко [та ін.]. К., 2008. 48 с.

4. Загальноєвропейські рекомендації 3 мовної освіти: вивчення, викладання, оцінювання. Відділ сучасних мов. К. : Ленвіт, 2003. 361 с.

5. Закон України «Про вищу освіту» URL: https:// zakon.rada.gov.ua/laws/show/1556-18 (дата звернення: 30.01.2020).

6. Іванишин Г. Реалізація концепції українськомовної підготовки іноземних громадян у типовій навчальній програмі для підготовчих фракультетів ВНЗ України. Теоретична і дидактична фрілологія. Серія «Педагогіка». 2015. Вип. 21. С. 21-29.
7. Колодько Т.М. Формування соціокультурної компетенції майбутніх вчителів іноземних мов у вищих педагогічних навчальних закладах : автореф. дис. ... канд. пед. наук: 13.00.04. К., 2005. 24 с.

8. Ліцензійні умови провадження освітньої діяльності. URL: https://zakon.rada.gov.ua/laws/ show $/ 1187-2015-\% D 0 \% B F$ ?find $=1 \&$ text $=\% D 1 \% 96 \%$ D0\%BD\%D0\%BE\%D0\%B7\%D0\%B5\%D0\%BC\%D0 \%BD\%D0\%B0\#w16 (дата звернення: 27.01.2020).

9. Національна рамка кваліфікацій України. URL: https://zakon.rada.gov.ua/laws/ show/1341-2011-\%D0\%BF/paran12\#n12 (дата звернення: 27.01.2020).

10. Олійник К.С. Характеристика комунікативної компетентності майбутніх соціальних працівників як невід'ємного складника професіоналізму. Інноваційна педагогіка. 2019. Вип. 18. Т. 2. С. 50-54.

11. Потюк I. Комунікативна компетенція як невід'ємний складник навчально-виховного процесу. Молодь і ринок. 2012. № 1 (84). C. $128-132$.

12. Річний звіт Національного агентства із забезпечення якості вищої освіти за 2019 рік / за заг. ред. проф. Сергія Квіта. К. : Національне агентство із забезпечення якості вищої освіти, 2020. 244 с. 